\title{
Practice Exam Program Impact on Student Academic Performance and Stu- dent Retention
}

\section{Ms. Dawn Patterson Shew M.Ed., University of Kansas}

Dawn Shew is the Director of Undergraduate Academic Services at the University of Kansas School of Engineering.

\section{Dr. Lorin P. Maletsky, University of Kansas}

Dr. Lorin Maletsky joined the Mechanical Engineering faculty at the University of Kansas in 2000. $\mathrm{He}$ is currently a full professor and serving as the Associate Dean for Undergraduate Programs in the School of Engineering. He has created and taught a project, team-based freshmen course in Mechanical Engineering as well as helped to develop different academic support programs across the school including Undergraduate Teaching Fellows to support active learning in the classroom, small-group tutoring in courses, and the Practice Exams.

\section{Grace Clark}

Dr. Molly McVey, University of Kansas

Dr. Molly A. McVey is a post-doctoral teaching fellow at the University of Kansas School of Engineering where she works with faculty to incorporate evidence-based and student-centered teaching methods, and to research the impacts of changes made to teaching on student learning and success. Dr. McVey earned her Ph.D in Mechanical Engineering from the University of Kansas. 


\section{Practice Exam Program Impact on Student Academic Performance and Student Retention}

Introduction. Retention of students in engineering programs continues to be a concern as schools try to increase enrollments and graduates. Retention rates in engineering from first to second year are the lowest among majors [1] and persistence to second year is only around 80\%, worse for some ethnic groups (2017 Engineering by the Numbers, ASEE Retention and Time-ToGraduation Benchmarks for Undergraduate Engineering Schools). This is due to a variety of factors including a challenging curricula, high credit loads, and students taking only a small number of courses in their major the first year.

It was recognized that college exams, especially for first-year students, are particularly difficult for students to succeed as they transitioned to college. Exam formats and expectations are different than what students experienced in high school and vary from class to class. Engineering majors report spending a greater amount of time preparing for classes and exams [2]. Many students new to college report that they don't know how to study and prepare for college exams [3], anecdotally reporting that in high school it was sufficient to simply read over notes. Most new students are also still building their support network of peers and may solely be studying on their own. Additionally, in many courses exams can comprise a significant portion of the final grade. Doing poorly on an exam can also have a negative effect on a student's confidence and desire to continue in a course or a major, especially for students in engineering who were typically strong students in high school. Even with the growing use of active classrooms and collaborative learning environments, exams are still generally done individually and can increase a student's feeling of stress, anxiety, and isolation. Students may also feel like an imposter with a perception that other students understand the material more than they do.

Another concern was high DFW rates (students earning a D, F, or withdrawing) for key service courses from the Engineering and Computer Science curricula taught outside of engineering during the first few semesters a student is at university. An increase in academic performance should increase retention in both engineering and to the university. Math courses posed a particular challenge, so efforts and assessment were focused on those courses. Roughly a quarter of incoming engineering freshmen were not yet qualified for Calculus, and Pre-Calculus had DFW rates above $40 \%$. Calculus I, the first math course for most incoming engineering students, had a DFW rate of $32 \%$ in Fall 2016. Calculus II had a DFW rate of 38\% and Calculus III over $40 \%$ in that same semester. In addition to providing knowledge necessary for application in future coursework, performance in Math courses is often a litmus test students use to determine whether they have the aptitude or fortitude to continue on to more rigorous engineering coursework. It seemed probable that otherwise able future engineers changed majors prematurely based on their negative performance in Math.

Academic support for courses frequently focuses on helping students who are having trouble as opposed to supporting students throughout their learning experience. "Help rooms" suggest that a student should go there when they need help. Office hours seem ideal for faculty, but many new students feel intimidated by college instructors and may not engage with the support until their grade is in trouble. The term "tutor" can carry a certain amount of stigma, and may suggest to students that they are not smart enough to be successful on their own. Participation in these 
academic support efforts can also be low throughout a semester and only spike the few session before exams.

All students including those in engineering benefit by developing strong study groups with their peers and collaborating throughout their undergraduate career. Engineering programs frequently contain team-based projects in courses that help students develop teamwork and management skills for use in their professional careers. Helping students work with their peers for academic support is an important skill that most successful students develop over time. This develops the necessary collaboration skills that today's students need to possess post-graduation.

Underclassmen also benefit by learning collaboratively from upperclassmen in their majors [4]. Additionally, students retain a larger quantity and higher quality of content by utilizing varied retrieval practice, which challenges learners to go beyond a simple read and recall study approach [3].

The authors created "Practice Exam Sessions," a sustainable academic support program with three main goals:

1. Support students in preparing for exams in courses foundational to engineering that can complement whatever instructors are doing in their classes with minimal effort on their part,

2. Increase retention among engineering students and progress to degree, and

3. Develop collaborations among students and develop active learning skills, and support peer-to-peer learning from upperclassmen.

The objective of this paper is to describe the implementation of the Practice Exam Program and present data related to success in the respective exams and courses and retention of the participants. We will finish with a discussion of the future of the program.

\section{Methods}

This section will start with a description of what a Practice Exam Session consisted of, followed by a discussion of the interaction with faculty and student groups, the marketing pieces that were developed, and the administrative components. The described study was approved by the Institutional Board of the University of Kansas.

The Practice Exam Session. The week before an exam in a supported course, students receive notification of a practice exam session, held outside of class on Sunday evening. The sessions are held in active learning classrooms, where students sit in tables of six to nine facing each other and there are white boards around the room. Exams supplied by the instructor are distributed to students after a short set of instructions about the process is explained. Exams are sometimes from prior semesters, but it is most effective to present novel exams to increase the incentive to attend. These practice exams are not offered outside of our session; we do not distribute them in any other fashion (e.g. posting online).

A practice exam session consists of three phases.

1. First, students work through the exam independently using whatever resources they would have during the actual exam. This could include review sheets, calculators, etc. This period lasts 30-40 minutes. During this time, no help is given on the problems other 
than what would be clarified during the real exam. The objective during this time is for students to understand what they know. This period is typically very quiet as students work independently.

2. In the second phase, students work collaboratively through the exam with their peers at their table. They are encouraged to continue to use whatever resources they would normally have during an exam, and not "check the book" or the internet. Again, during this time students are not given assistance from tutors or other helpers. The objective during this time is for students to talk about the material with their peers and build support and confidence in themselves and their peer group, while also identifying areas that they need to review before the real exam. This period takes around 30 minutes and is usually quite loud and animated. Though instructors are not required to attend, instructors who have attended during this phase find it is a perfect time to walk around the room and get a good understanding of what students really know and where they need help.

3. After the first two phases, roughly an hour in, the facilitator (usually student staff) goes through the answers to the exam (not the solution) and students self-grade their work. During this time members of student organizations, who have studied the exam solutions, array themselves around the periphery of the room. They write the problem numbers they will work through on the board. Participating students then move around the room, going to the problems where they had difficulty. Student helpers will work through any of the problems as needed. Participants who feel prepared may elect to leave; those who identified areas they need to work on will stay and talk with upperclassmen and tutors until they understand that material. This period can range up to one hour, but students will stay for as long as they have questions.

Institutional Factors. The University of Kansas has an enrollment of just over 28,500 students. The KU School of Engineering has an undergraduate enrollment of around 2,300 students. Students in all Engineering disciplines must earn passing grades in Calculus I, II, and Physics I and II. Additionally, most Engineering disciplines must also take one of two basic Chemistry courses. This foundational coursework is offered outside of the School of Engineering, through the KU College of Liberal Arts and Sciences. Enrollment in Calculus I requires a 28 Math ACT (or SAT equivalent), prior collegiate coursework in Pre-Calculus, or qualifying scores $(\geq 3)$ on relevant Math AP exams. Similarly, enrollment in freshman Chemistry coursework requires a 26 Math ACT (or SAT equivalent), prior collegiate coursework in Pre-Calculus, or qualifying scores $(\geq 3)$ on relevant Math AP exams. The majority $(70 \%)$ of incoming Engineering freshmen are Calculus I eligible in their first semester; the remainder take Pre-Calculus initially. With the exception of Chemistry for Engineers and Physics for Engineers, students of all disciplines (typically STEM majors) take the courses together; for example, roughly $69 \%$ of all students enrolled in Calculus I are admitted or pre-Engineering students. Most instructional modes for these courses include a large lecture format, supported by a discussion/lab portion on alternate days. Typical enrollments in these sections vary, but are regularly over 200 students.

Courses Supported. The current practice exam sessions support Math, Physics, and Chemistry courses that are required for the engineering majors. These courses have been identified as courses that engineering students have trouble with and have historically had high DFW rates. The foundational courses that most engineers at our University take include Calculus 1, 2, and 3; Physics 1 and 2; and Chemistry 1 and 2. Beyond that, additional courses based on the number of 
engineering students that are enrolled in the course are supported. For example, many of our students take Pre-Calculus in their first semester, so this is supported in the Fall but not in the Spring. Because these sessions have run for a number of semesters, it is possible to predict the number of attendees based on where in the sequence the course falls. Calculus 1, for example, is usually taken in the Fall semester. Therefore, more students are expected at the Fall Calculus 1 Practice Exams than at the Spring sessions. Practice exams are open to all KU students, regardless of major. Practice exams are offered for all non-final exams, which varies from course to course.

Communication with Instructors. Good communication and interaction between the engineering staff and the instructors of the courses is very important. As one of the program's goals is to support engineering students in their Math, Physics, and Chemistry courses, it is important that the practice exam materials shared with students are representative of what students can expect to see on the actual exam. This is achieved through frequent communication with instructors. In the few weeks prior to the start of the semester, instructors receive an email that describes the practice exam format, as well as a request for exam dates so that practice exam dates can be set. Engineering commits to not share exam solutions with students outside of the exam, or permit photographs of solutions, although many instructors will make both the exam and solution available on their own course websites, preferably after the practice exam session. Pertinent information from the sessions, such as attendance, and any concepts that gave students trouble are shared with the instructor so that they can review in class if desired.

Accessing Exams to Administer. At the beginning of each week prior to an exam, instructors of that course are asked to provide feedback on the most recently used practice exam on file for their course, or provide a more recent and relevant exam. Exams vary in length and type based on the instructor. Program facilitators confirm whether material on the exam has been covered, and whether there is additional information the instructor has covered that is not on the exam. At that time, instructors also receive a flyer for the upcoming practice exam that they can distribute to students. Program materials are copied the Friday prior to the practice exam session and administrators are available Sunday night to make additional copies if required. The exam bank consists of exams that have been collected from professors since the program began in Spring 2017. Multiple choice practice exams tend to lend themselves better to this format because the problems tend to be a little simpler and it is easier to identify if you have the correct answer compared to long, involved solutions which present some obstacles, though these have been supported as well. Our surveys found that encouragement from instructors were the most common reason why our participants knew about and chose to attend the practice exams.

Active Learning Classrooms. New active learning classrooms are also an important resource in the effectiveness of this program. During group time, students are able to more easily engage with their tablemates. These spaces make it possible for students to move freely around the room compared to a traditional lecture hall. They are also equipped with wipe boards on each wall, which provide ample space for helpers to work problems and illustrate solutions. Prior to the start of the semester, active learning classrooms are reserved on Sundays from 6:30 to 9:00 pm. Once all of the practice exam dates have been set, courses are assigned to rooms based on size and anticipated turnout. Backup rooms are also reserved in case there is overflow in the primary room which occurs occasionally because attendance is not known beforehand. At times, some 
exams are held earlier in the day due to a conflict with another event, a lack of space, or if two courses typically taken concurrently are scheduled for practice exams on the same day. For example, most students take Calculus 1 and Chemistry 1 at the same time. On the weeks where both of those courses have exams, one of the practice exams is scheduled at 4:00 pm and the other at 7:00 pm, allowing students to attend both exam sessions. Extra classrooms are reserved for courses with large enrollments. In the event that a classroom fills, the same experience is offered in another, nearby classroom. The end review portion then takes place in the largest room.

Involvement of Student Organizations. The Practice Exam program provides academic help through a partnership with engineering administration and student organizations. Program administrators begin identifying students groups available to help with the sessions at the end of the prior semester. Each student group is assigned to an academic course. Groups are asked to provide 4-6 helpers when 150 students or less are expected. When more than 150 attendees are expected, groups are asked to provide 8-10 helpers. If organizations cannot provide that many helpers, two student groups may be paired together. The dates of the practice exams are shared with student groups prior to the start of the semester. Once the semester starts, student groups are reminded about the upcoming exam around the middle of the week. Student group members arrive roughly when the practice exam starts or around 7:15 and meet nearby where they are given the solution to the exam. They normally have 45-60 minutes to review the solution and make sure they can work through the problems. The exam questions are divided amongst student helpers, with each helper taking a roughly equal number of questions. They are then responsible for learning the solution, working through the solution on the board, and answering any related questions. This method seems to work well since helpers individually do not need to be able to provide solutions to the entire exam. Student groups are paid $\$ 100$ per session.

Promotional Materials. Program administrators communicate with students through email, posters, and flyers. Prior to the start of the semester, signs that list the dates of upcoming practice exams are posted throughout the engineering buildings. On the Wednesday before the practice exam, engineering students receive an email about the upcoming session. This is the only promotional material that is exclusive to engineers, though any major who attends may participate. On the Thursday prior to the exam, large posters are placed in the atrium of the main engineering building alerting students of the exams that weekend. Most instructors will advertise the sessions in their class. Posters and flyers list the dates, times, and locations of upcoming practice exam sessions. Marketing materials also display the program's slogan, 'Practice Exams make Perfect Exams,' and a quick overview of the program's goals and setup.

Facilitators. Student workers are hired as facilitators who help administer the Practice Exam Sessions by greeting students as they arrive, making sure attendance is taken, passing out exams, answering student questions, sharing solutions with student groups, and collecting all exam materials at the end of the exam. Facilitators arrive at 6:30pm, post signs, and greet and guide participants. The number of facilitators needed depends on the number of students expected, and the number of exams being covered. Typically, there is one facilitator per exam. Students begin arriving around 6:45 pm and are asked to sign in with their name and ID number. These sheets are collected by the facilitator after the start of the exam. The sign-in sheets help keep track of how many and which students are attending. These students have completed all of the courses 
that are offered and can also answer questions about the exams. Tutors have successfully been used as facilitators.

Administrative Support. It is estimated that it takes approximately 15 hours per week to administer the Practice Exam Program. A faculty administrator, such as an Associate Dean, initiates the communication with departments and instructors to ensure their support as well as solicits student groups to participate. A senior staff member, such as the Director of Undergraduate Programs, emails engineering students prior to the practice exam sessions, and communicates with the staff. Other tasks include printing and displaying marketing materials, making sure exams, solutions, and sign-in sheets are copied, communicating with instructors and student groups, and attending the actual sessions to provide support for the facilitators. At the practice exam sessions, staff post signs for the day's sessions, helps direct students to the proper exam rooms, gives exam materials to facilitators, collects the sign-in sheets, and monitors the session to make sure things run smoothly. These staff can also facilitate sessions when an additional facilitator is needed.

Budget. Personnel expenses include staff FTE (around 15 hours a week) and student hourlies (6 hours per week). Additional costs include supporting student group helpers and supplies such as copies, paper, dry erase markers, etc. A challenge of this program is that attendance is not known in advance. A need may arise for last minute copies, or more staff, which can increase expense. For the implementation of the Practice Exam Program we have paid student employees $\$ 10$ per hour and student groups $\$ 100$ per practice exam session they support. Currently, the budget for the Practice Exam Program is around \$7,000 per year to support 8-10 courses per semester with practice exams, which has been generously provided by a donor to continue running the program for five years.

Testapalooza. Invariably during a semester there is one week which has a large number of exams. This creates more practice exams than can be accommodated during one time slot from $7 \mathrm{pm}-9 \mathrm{pm}$. Also, students are often in more than one class being covered. On such a Sunday when it is required to hold two separate practice exam sessions to accommodate all the exams that week, an event called Testapalooza is done. The two exam sessions are scheduled for 4:00 pm and 7:00 pm. Food is provided for students between the exams. Additionally, other campus offices are invited to table at the event, including career services, counseling, offices for students who might need testing or study accommodations, and study abroad. This gives students an opportunity to find out more about counseling and tutoring, and is timely, as the event typically occurs around the first big round of tests. The convergence of multiple exams can be stressful and anxiety ridden for first year students. Typically, 600-700 practice exams are administered at this event, to approximately 400 unique participants, spanning between five and seven exams.

\section{Results}

Courses Supported. The practice exam program debuted in Spring 2017 with only four course offerings: Physics I, Calculus I and II, and Chemistry II. 239 unique students were served in that semester, with roughly $10 \%$ returning for more than one subject. The program took off immediately; 1,037 unique students were served in Fall 2017 and 968 in Fall 2018. Spring 
attendance tends to be lower than Fall, largely because students have formed new connections and have a higher level of comfort taking exams as college students.

Measuring Effectiveness. Directly measuring the relationship between the Practice Exam Program and retention rates are difficult, so other metrics were investigated. DFW rates of students in courses that were supported were measured to assess program success. This measure was available for all participating students, who were both engineering and non-engineering students. The results were noticeable, as evidenced in the data from Fall 2018 (Table 1). The data showed a positive correlation between attendance at Practice Exam Sessions and likelihood of earning a $\mathrm{C}$ or better in the course (students who do not earn D, F, or W). Students who attended either one or both practice exam sessions had a greatly decreased chance of not earning at least a grade of $\mathrm{C}$ in the course. Approximately half of the students in each course participated in at least one practice exam, with Pre-Calculus showing the least participation. In three of the four math courses examined the DFW rates decreased in the semester the Practice Exam Program was utilized.

Table 1: DFW Rates for Students as a Function of Attendance at Practice Exam (PE) Sessions, Math Courses, Fall 2018

\begin{tabular}{|c|c|c|}
\hline \multirow[b]{2}{*}{$\begin{array}{l}\text { Total Pre-Calculus } \\
\text { enrollment: } 276\end{array}$} & $\begin{array}{l}\text { Total PE } \\
\text { Participation: }\end{array}$ & $40.22 \%$ \\
\hline & $\begin{array}{l}\% \text { of total } \\
\text { enrolled }\end{array}$ & $\begin{array}{l}\text { Participant } \\
\text { DFW \% }\end{array}$ \\
\hline Both Practice Exams & $15.22 \%$ & $0.36 \%$ \\
\hline One Exam & $25.00 \%$ & $5.07 \%$ \\
\hline NO PE & $63.04 \%$ & $26.81 \%$ \\
\hline All Pre-Calculus & $100.00 \%$ & $32.25 \%$ \\
\hline \multicolumn{2}{|c|}{ Fall 2015 and 2016 DFW Average } & $37.10 \%$ \\
\hline & $\begin{array}{r}\% \\
\text { improvement }\end{array}$ & $4.85 \%$ \\
\hline
\end{tabular}

\begin{tabular}{|c|c|c|}
\hline \multirow[b]{2}{*}{$\begin{array}{l}\text { Total Calculus I } \\
\text { enrollment: } 502\end{array}$} & $\begin{array}{l}\text { Total PE } \\
\text { Participation: }\end{array}$ & $50.80 \%$ \\
\hline & $\begin{array}{l}\% \text { of total } \\
\text { enrolled }\end{array}$ & $\begin{array}{l}\text { Participant } \\
\text { DFW \% }\end{array}$ \\
\hline $\begin{array}{l}\text { Both Practice } \\
\text { Exams }\end{array}$ & $30.88 \%$ & $2.39 \%$ \\
\hline One Exam & $19.92 \%$ & $4.58 \%$ \\
\hline NO PE & $49.20 \%$ & $21.91 \%$ \\
\hline All Calculus I & $100.00 \%$ & $28.88 \%$ \\
\hline \multicolumn{2}{|c|}{ Fall 2015 and 2016 DFW Average } & $33.90 \%$ \\
\hline & $\begin{array}{r}\% \\
\text { improvement }\end{array}$ & $5.02 \%$ \\
\hline
\end{tabular}

\begin{tabular}{|c|c|c|}
\hline \multirow[b]{2}{*}{$\begin{array}{l}\text { Total Calculus II } \\
\text { enrollment: } 283\end{array}$} & $\begin{array}{l}\text { Total PE } \\
\text { Participation: }\end{array}$ & $54.77 \%$ \\
\hline & $\begin{array}{l}\% \text { of total } \\
\text { enrolled }\end{array}$ & $\begin{array}{l}\text { Participant } \\
\text { DFW \% }\end{array}$ \\
\hline Both Practice Exams & $23.67 \%$ & $3.18 \%$ \\
\hline One Exam & $31.10 \%$ & $9.89 \%$ \\
\hline NO PE & $45.23 \%$ & $27.92 \%$ \\
\hline All Calculus II & $100.00 \%$ & $40.99 \%$ \\
\hline \multirow{2}{*}{\multicolumn{2}{|c|}{$\begin{array}{r}\text { Fall } 2015 \text { and } 2016 \text { DFW Average } \\
\% \\
\text { improvement }\end{array}$}} & $39.10 \%$ \\
\hline & & $-1.89 \%$ \\
\hline
\end{tabular}

\begin{tabular}{|c|c|c|}
\hline \multirow[b]{2}{*}{$\begin{array}{l}\text { Total Calculus III } \\
\text { enrollment: } 386\end{array}$} & $\begin{array}{l}\text { Total PE } \\
\text { Participation: }\end{array}$ & $47.41 \%$ \\
\hline & $\begin{array}{l}\% \text { of total } \\
\text { enrolled }\end{array}$ & $\begin{array}{l}\text { Participant } \\
\text { DFW \% }\end{array}$ \\
\hline $\begin{array}{l}\text { Both Practice } \\
\text { Exams } \\
\end{array}$ & $20.21 \%$ & $0.78 \%$ \\
\hline One Exam & $27.20 \%$ & $4.15 \%$ \\
\hline NO PE & $52.59 \%$ & $14.51 \%$ \\
\hline All Calculus III & $100.00 \%$ & $19.43 \%$ \\
\hline \multicolumn{2}{|c|}{ Fall 2015 and 2016 DFW Average } & $39.10 \%$ \\
\hline & improvement & $19.67 \%$ \\
\hline
\end{tabular}

The program aimed to help students achieve more than simply not failing but to also help them thrive in their courses and higher final grades was one measure of success in this area (Table 2). Students who attended at least one practice exam session earned a higher GPA in their Math 
course, and attending both sessions increased moreso. The overall GPA in these courses did not change appreciably from years past (Table 3), likely because non-participants remained at least half of the enrollment in each course, and achieved roughly the same or worse grades as they did before the program began.

Table 2: Average Course GPA of Students as a Function of Attendance at Practice Exam Sessions, Fall 2018

\begin{tabular}{|l|l|l|}
\hline \multicolumn{1}{|c|}{ Pre-calculus } & \multicolumn{1}{|c|}{$\begin{array}{c}\text { C } \\
\text { students }\end{array}$} & $\begin{array}{c}\text { Course } \\
\text { GPA }\end{array}$ \\
\hline $\begin{array}{l}\text { Both Practice } \\
\text { Exams }\end{array}$ & 41 & 3.46 \\
\hline One Practice Exam & 80 & 2.80 \\
\hline No Practice Exams & 169 & 2.06 \\
\hline Total w/ grade & 290 & 2.46 \\
\hline
\end{tabular}

\begin{tabular}{|l|r|l|}
\hline \multicolumn{1}{|c|}{ Calculus I } & \multicolumn{1}{|c|}{$\begin{array}{c}\# \\
\text { students }\end{array}$} & $\begin{array}{c}\text { Course } \\
\text { GPA }\end{array}$ \\
\hline $\begin{array}{l}\text { Both Practice } \\
\text { Exams }\end{array}$ & 151 & 3.21 \\
\hline $\begin{array}{l}\text { One Practice } \\
\text { Exam }\end{array}$ & 93 & 2.78 \\
\hline $\begin{array}{l}\text { No Practice } \\
\text { Exams }\end{array}$ & 200 & 2.20 \\
\hline Total w/ grade & 444 & 2.65 \\
\hline
\end{tabular}

\begin{tabular}{|l|l|l|}
\hline \multicolumn{1}{|c|}{ Calculus II } & \multicolumn{1}{|c|}{$\begin{array}{c}\# \\
\text { students }\end{array}$} & $\begin{array}{c}\text { Course } \\
\text { GPA }\end{array}$ \\
\hline $\begin{array}{l}\text { Both Practice } \\
\text { Exams }\end{array}$ & 63 & 3.05 \\
\hline One Practice Exam & 78 & 2.63 \\
\hline No Practice Exams & 103 & 1.48 \\
\hline Total w/ grade & 244 & 2.24 \\
\hline
\end{tabular}

\begin{tabular}{|l|r|l|}
\hline \multicolumn{1}{|c|}{ Calculus III } & \multicolumn{1}{|c|}{$\begin{array}{c}\# \\
\text { students }\end{array}$} & $\begin{array}{c}\text { Course } \\
\text { GPA }\end{array}$ \\
\hline $\begin{array}{l}\text { Both Practice } \\
\text { Exams }\end{array}$ & 78 & 3.03 \\
\hline $\begin{array}{l}\text { One Practice } \\
\text { Exam }\end{array}$ & 105 & 2.65 \\
\hline $\begin{array}{l}\text { No Practice } \\
\text { Exams }\end{array}$ & 192 & 2.20 \\
\hline Total w/ grade & 375 & 2.50 \\
\hline
\end{tabular}

Table 3: Average Course GPA of Students in Math courses, Fall 2015-2018

\begin{tabular}{|c|c|c|c|c|}
\hline \multirow{2}{*}{ Math } & $\begin{array}{c}\text { Fall } \\
\text { 2015 }\end{array}$ & $\begin{array}{c}\text { Fall } \\
\text { 2016 } \\
\text { Avg }\end{array}$ & $\begin{array}{c}\text { Fall } \\
\text { 2017 } \\
\text { Avg } \\
\text { Gvg }\end{array}$ & $\begin{array}{c}\text { Fall } \\
\text { 2018 } \\
\text { Avg } \\
\text { GPA }\end{array}$ \\
\hline Precalculus & 2.25 & 1.88 & 2.44 & 2.46 \\
\hline Calculus I & 2.6 & 2.68 & 2.68 & 2.65 \\
\hline Calculus II & 2.18 & 2.38 & 2.30 & 2.24 \\
\hline Calculus III & n/a & 2.11 & 2.45 & 2.55 \\
\hline
\end{tabular}

With the observed positive trends with practice exam participation and DFW rate and course GPA, it was felt that the data could be skewed by the innate abilities participating students likely brought to the coursework. More successful students, it was posited, would be more likely to use the resource, and so already more likely to perform well in Math courses. Since performance in Math courses follows Math ACT data closely, examining Math ACT scores was a good assessment of whether our "higher achieving" students were doing well because they already possessed habits that lead to academic success, or were truly improved by the program. It was hypothesized that participants would have higher Math ACT scores than our non-participants (Table 4). For this data set, only engineering student information was available to the authors. 
The results were not anticipated; in general, non-participants had a higher Math ACT score, had lower course GPAs, and were more likely to earn a DFW.

Table 4. Average Math ACT Relative to Math Practice Exam

Participation,

Engineering Students Only, Fall 2018

\begin{tabular}{|c|c|c|c|c|c|}
\hline $\begin{array}{l}\text { Pre- } \\
\text { calculus }\end{array}$ & $\begin{array}{c}\# \\
\text { students }\end{array}$ & $\begin{array}{l}\text { Avg } \\
\text { ACT }\end{array}$ & $\begin{array}{l}\text { Calculus } \\
\text { I }\end{array}$ & $\begin{array}{c}\# \\
\text { students }\end{array}$ & $\begin{array}{l}\text { Avg } \\
\text { ACT }\end{array}$ \\
\hline Any Exams & 50 & 24.91 & $\begin{array}{l}\text { Any } \\
\text { Exams }\end{array}$ & 194 & 28.74 \\
\hline No Exams & 52 & 25.37 & No Exams & 112 & 29.29 \\
\hline Calculus II & $\begin{array}{c}\# \\
\text { students } \\
\end{array}$ & $\begin{array}{l}\text { Avg } \\
\text { ACT }\end{array}$ & $\begin{array}{l}\text { Calculus } \\
\text { III }\end{array}$ & $\begin{array}{c}\# \\
\text { students }\end{array}$ & $\begin{array}{r}\text { Avg } \\
\text { ACT } \\
\end{array}$ \\
\hline Any Exams & 110 & 28.43 & $\begin{array}{l}\text { Any } \\
\text { Exams }\end{array}$ & 145 & 28.06 \\
\hline No Exams & 59 & 28.2 & No Exams & 137 & 29.1 \\
\hline
\end{tabular}

Ultimately, our primary goal was to improve performance in all populations. Typically, the lower Math ACT a student has, the lower we would expect their earned grade to be. This is especially true for incoming students in their initial semester, because other factors like familiarity with the institution or course format are at their lowest. Ideally, participating students should outperform non-participants regardless of the incoming Math scores. In fact, this is what we observed (chart A). The chart below compares average GPA (with W being calculated as 0 grade points) for participating and non-participating students at each Math ACT point.

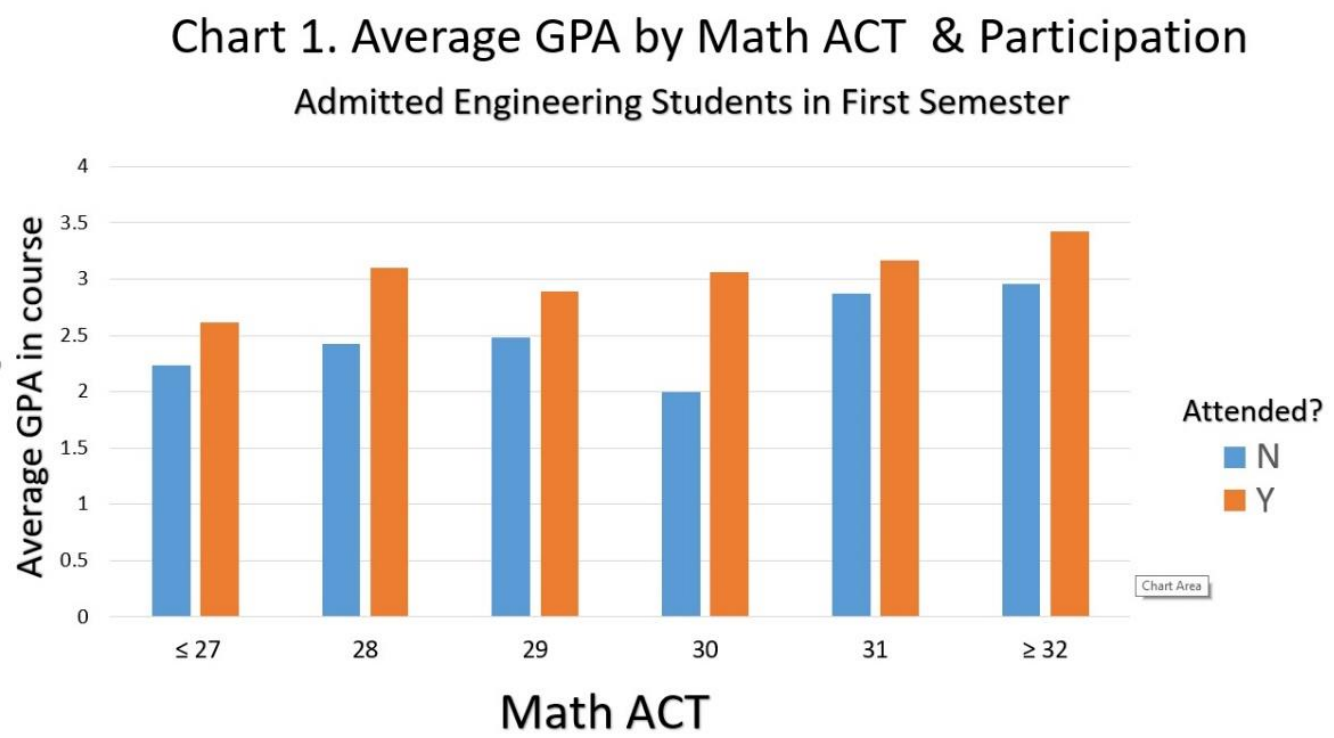

Placement exams such as the ACT are a measure of math readiness, but do not speak to whether students are "college ready." To be sure, there are many other factors that affect a student's ability to excel in college. Will the student have to work? Have they developed positive study habits? How are they prepared mentally for the rigors of advanced math? Anecdotally, another 
driving motivator for the development of this program were students who reported that though they felt adequately prepared for their exams from a content perspective, they were wholly unprepared for the stress and strain of taking an exam in a room with large groups of students. These students reported a sense of anxiety and lack of preparation for exams, which clouded their ability to recall content and score well. We surveyed all students in the courses we support to assess whether they perceived that the practice exam was relevant and helpful as they prepared for exams. We used this survey to assess student satisfaction, and gain input on how to improve the program (Table 5).

Table 5: Student Satisfaction Survey Responses

\begin{tabular}{|l|c|c|}
\hline \multicolumn{1}{|c|}{ Student Strongly Agreed/Agreed } & Fall & Fall \\
$\mathbf{2 0 1 7}$ & $\mathbf{2 0 1 8}$ \\
\hline Practice exam content was relevant & $90 \%$ & $99 \%$ \\
\hline Practice exam was a good use of study time & $90 \%$ & $97 \%$ \\
\hline Likey to attend in the future & $89 \%$ & $94 \%$ \\
\hline
\end{tabular}

In the comment areas of these surveys, many students reported that they appreciated the opportunity to work with their peers on problems when the individual time was over. One student volunteered, "I didn't know anyone when I came to KU, and now I sit with the same kids at all the exams. Some of them live in my hall and we study together outside of here, too." While it is difficult to quantify these relationships, research shows that making these kinds of connections plays a vital role in persistence and retention [5]. In addition to working with peers, students also appreciated the opportunity to be guided by upperclassmen. Some shared that they felt the student organization helpers "really knew what (they) were going through, since they went through the same things."

Students surveyed overwhelmingly reported an intent to return. That intention bears out when we sample Fall 2018 Calculus III attendees. Nearly three quarters of the students who took Calculus III practice exams in Fall 2018 took other practice exams in that same semester. Moreover, nearly nine in ten of these students had taken at least one practice exam during the two semesters prior to Fall 2018. Seventy-three percent of students who took the Calculus I practice exam in Fall 2017 attended future practice exam sessions.

The goal to reduce DFW was directly aimed at retaining more students to Engineering. $85 \%$ of the Engineering participants from Fall 2017 were retained to engineering in Fall 2018. While not all practice exam participants are first-year students, they do constitute the majority; the courses offered are largely in the freshman year of engineering curricula. By contrast, retention of all full-time, first-time freshmen to the school was $70.5 \%$ over the same time period.

Limitations. The current iteration of most of the courses supported by this program began around Fall 2015. The calculus sequence, for example, was offered in two courses rather than the present three. Because of this, comparing current outcomes to past performance is not possible (as this program began almost immediately.) Additionally, though the data show positive outcomes for participants, it is difficult to pinpoint exactly what about the practice exam explains this 
improvement. Because non-participants may not have had access to the same exams, for example, it is possible that the exam presented through this program is simply superior to other resources available to students. Conversely, it could be the participative aspect of this program that makes it more effective than independent study. There are countless varying factors that impact student performance, both within and outside of the practice exam program.

\section{Discussion}

Our data show that the aims of the Practice Exam Program to increase student success in foundational courses have been met. The program routinely serves around 1000 unique students each semester; since this is a voluntary program not directly linked to a grade, participation is a good measure of success. The data show strong and positive correlations between participation in the practice exam sessions and reduced DFW rates and increased course GPA. Overall DFW rates in Math classes have decreased by up to $20 \%$, showing the impact on the class overall. Students who participate in the practice exam sessions are more likely to earn at least a $\mathrm{C}$ in the course, even though indicative ACT scores might predict a lower GPA than their nonparticipating peers with higher ACT scores. A student who did not attend a practice exam session was around 4-times more likely to earn a D, fail the course, or choose to withdraw. These students appear to have a high level of satisfaction with the program, and retain at a higher rate than that of their cohort generally. Around nine out of ten participating students are also likely to continue to return to subsequent practice exams, which indicates that they feel the experience and the content is relevant and worthwhile. The practice exam program is fairly economical, producing impressive results for the cost per participant. These data suggest that the Practice Exam Sessions are having a positive impact of the academic performance of the students who participate.

As the Practice Exam Program has become routine, there has been a cultural shift in the School of Engineering. Students expect the Practice Exam Program in these early courses; it has become more of a norm to have them. Roughly $10-20 \%$ of enrolled students in courses attended practice exams initially in Spring 2017. It is now usual to see 50\% of those enrolled attend these sessions. It is anticipated that this will continue, so long as the content remains relevant, and it is a high quality program that serves students' needs. Students have requested that the program expand our practice exam offerings to upper level engineering courses. However, though we do allow any student to attend, the resources are primarily dedicated to assisting those engineering students who are early in their academic career, in foundational coursework.

There have been benefits to the Practice Exam Program that were unanticipated. The relationship between engineering staff and course instructors (who are not in the School of Engineering) has been strengthened. Because of the feedback to instructors about content that participants find problematic, instructors often choose to focus on those areas during their own in-class reviews prior to exams. Many of the supported courses also serve students outside of engineering and it is hoped that some students may consider transferring into an engineering major after they have interacted with our staff and student groups. Additionally, students who participated as freshmen in Spring 2017 are beginning to return as upperclassmen student organization helpers. They report a sense of belonging to the engineering community, and enjoy the ability to give back to 
the program. Some student organizations who help have seen an increase in student membership, though this is a facet of the program that is not currently ideally leveraged.

There are limitations in the program that have yet to be addressed. For example, surveyed students were consistent in their requests for practice exams for final exams. However, we have yet to find ideal substitutes for our student helpers, who are busy preparing for their own final exams during this time. The practice exam sessions are at a difficult time for out-of-town commuters; there are many demands on the space we utilize throughout the week. Because attendance is walk-in, there is sometimes a last minute need for more exam copies, and this means students may have to wait to begin. The authors have yet to assess the effect on the practice exam program on the students helping to support the exams. We wonder whether it increases satisfaction for these students with their educational experience. Does it increase their sense of connection to the school and their student peers? There are many questions still to be answered beyond the positive academic results we have seen. It is worth looking further into the experience students have by participating in any role, and how that translates to the whole of their collegiate experience.

\section{References}

1. Itzler and Young, "Understanding the Risk of Attrition in Undergraduate Engineering: Results from the Project to Assess Climate in Engineering." Journal of Engineering Education, Vol. 101, No. 2, pp, 319-345

2. Lichtenstein, G. , McCormick, A. C., Sheppard, S. D. and Puma, J, "Comparing the Undergraduate Experience of Engineers to All Other Majors: Significant Differences are Programmatic.” Journal of Engineering Education, 99: 305-317, October 2010.

3. Felder and R. Brent, "Why Students Fail Tests: 1. Ineffective Studying." Chem. Engr. Education, 50(2), 151-152 (Spring 2016).

4. Newcomb and Bagwell, "Collaborative Learning in an Introduction to Psychological Science Laboratory: Undergraduate Teaching Fellows Teach to Learn.” Teaching of Psychology, April 1997, Vol. 24(2), pp. 88-95.

5. V. Tinto, "Taking Retention Seriously: Rethinking the First Year of College," NACADA Journal, Vol. 19, No. 2, pp. 5-9, 1999. 